\title{
First Korean Report of Powdery Mildew on Tropaeolum majus
}

\author{
Mi-Jeong Park ${ }^{1}$, Jin-Young Kim ${ }^{2}$, Jae-Gu Han ${ }^{1}$ and Hyeon-Dong Shin ${ }^{1 *}$ \\ ${ }^{1}$ Division of Environmental Science and Ecological Engineering, Korea University, Seoul 136-701, Korea \\ ${ }^{2}$ Gyeonggi-Do Agricultural Research \& Extension Services, Hwaseong 445-300, Korea \\ (Received on February 9, 2010; Accepted on March 19, 2010)
}

Garden nasturtium (Tropaeolum majus L.) is a herbaceous plant with beautiful red flowers, native to South America. In Korea it is widely planted as an ornamental in pots and flower beds. In October 2008, several plants showing typical symptoms of powdery mildew were found in Yongin, Korea. The disease usually started as chlorotic leaf lesions without definite margins, which later developed into

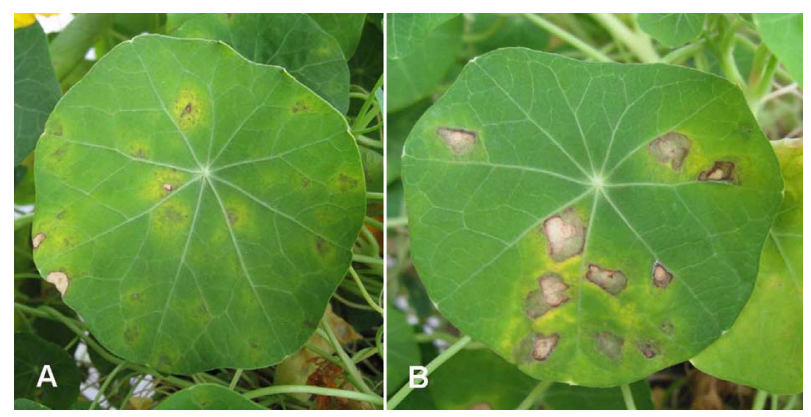

Fig. 1. Powdery mildew infection on leaves of Tropaeolum majus caused by Oidiopsis haplophylli. Note chlorotic lesions (A) and angular spots with necrosis (B) on the leaves.

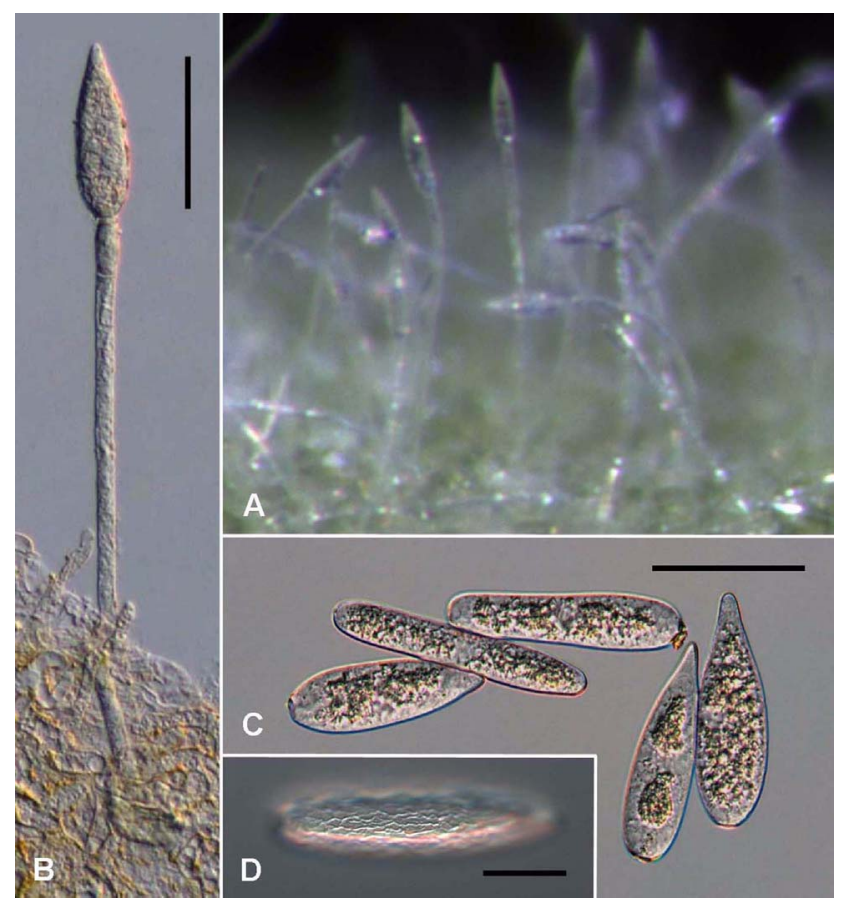

Fig. 2. Oidiopsis haplophylli associated with powdery mildew infection of Tropaeolum majus. A: Mass of conidiophores arising on the abaxial leaf surface. B: A conidiophore bearing primary conidium. C: Conidia. Note that three primary conidia are navicular and two secondary ones are cylindric. D: Surface structure of a primary conidium. Scale bar $=50 \mu \mathrm{m}$ for $\mathrm{B} \& \mathrm{C}$ and $20 \mu \mathrm{m}$ for $\mathrm{D}$. necrotic angular leaf spots with definite margins (Fig. 1). Even with weak infections, the plants often detract from the beauty of glossy leaves. The whitish fungal structures appeared on the abaxial leaf surface (Fig. 2A). Mild infection on the flower, causing chlorotic discoloration, was also noticed. A voucher specimen was deposited in Korea University herbarium (KUS-F23743).

Observations on the light microscope (Zeiss AX10 and Olympus BX51) revealed that mycelium is predominantly endophytic with the presence of conidiophores emerging through stomatal openings (Fig. 2B). The conidiophores were hyaline, cylindrical, 160-320 $\times$ 4.5-6 $\mu \mathrm{m}$, simple or occasionally branched one or two times at random positions, producing conidia singly, followed by 2-3 straight cells (Fig. 2B). Conidia were dimorphic, with primary conidia navicular, $60-82 \times 15-25 \mu \mathrm{m}$, and secondary conidia oblongelliptical to cylindric, $54-90 \times 14-20 \mu \mathrm{m}$; both hyaline, occasionally seen as pale brownish or greenish due to dense cytoplasm, lacking distinct fibrosin bodies, with angular/reticulated wrinkling of outer wall (Fig. 2C\&D). No chasmothecia were found in our observations.

According to Braun et al. (2002), Erysiphales anamorphs that have conidiophores arising from internal mycelium and have dimorphic conidia belong to the form-genus Oidiopsis. The detailed features of this fungus were in accordance with Oidiopsis haplophylli (H. Magn.) Rulamort, anamorph of Leveillula taurica (Braun, 1987). There are many previous records of $O$. haplophylli attacking garden nasturtium worldwide (Reis et al., 2007; Farr and Rossman, 2009). To our knowledge, however, this is the first record as a pathogen of T. majus in Korea.

Occurrence of powdery mildew on T. majus, as far as we observed, was restricted to the pot-grown plants which were placed in poor lighting condition in Yongin. No infections were found in the plants growing in outdoor flower beds, in spite of careful observations in several localities including Yangpyeong. Therefore it is highly recommended to avoid powdery mildew infections that garden nasturtium should be grown in sunny, well-ventilated nursery. Nevertheless, powdery mildew infection on garden nasturtium is a potential threat for safe production of seedlings in nursery business.

\section{References}

Braun, U. 1987. A monograph of the Erysiphales (powdery mildews). Beiheft zur Nova Hedwigia 89:1-700.

Braun, U., Cook, R. T. A., Inman, A. J. and Shin, H. D. 2002. The taxonomy of the powdery mildew fungi. In: The Powdery Mildews: A Comprehensive Treatise, ed. by R. R. Bélanger, A. Dik and W. Bushnell. APS Press, St. Paul, Minnesota, USA.

Farr, D. F. and Rossman, A. Y. 2009. Fungal Databases, Systematic Mycology and Microbiology Laboratory, ARS, USDA. Retrieved December 15, 2009, from http://nt.ars-grin.gov/fungaldatabases/

Reis, A., Boiteux, L. S. and Paz-Lima, M. L. 2007. Powdery mildew of ornamental species caused by Oidiopsis haplophylli in Brazil. Summa Phytopathologica 33:405-408.

*Corresponding author (hdshin@korea.ac.kr) 